\title{
The New Zealand full employment goal: a survey of changing views 1950 to 1980 .
}

\author{
Tony Endres*
}

Attitudes to full employment in official publications have varied. There have been changes in view as to the content, meaning and ranking of full employment in comparison to other objectives, and as to the significance of trade-offs between full employment and other objectives. Full employment conceived as total employment was worshipped at the beginning of the period under review. It was worshipped with less fervour in the 1960s. Opinions differed over what should have been done to reduce unemployment in the short-term as opposed to long-term and over what level of unemployment represented failure to achieve "full employment". Perceived opportunity costs - in terms of foregoing other objectives - of pursuing full employment more intensely, increased over the 30-year period. By the end of the period the notion of full employment was losing its connotation of prolonged job security.

\section{Introduction}

This is a study of policymakers' views regarding the goal of "full employment" in New Zealand from 1950 to 1980 . For my purposes, "policymakers" include government officials, government politicians and those generally accepted as quasi-official policy advisors. By "policy" relating to the goal of full employment is meant actual choices, actions, programmes and more specific statements made by policymakers in connection with this goal. The following questions act as a framework:

(1) How has full employment been perceived in New Zealand from 1950 to 1980 ?

(2) When and how was pursuit of this goal seen to be creating conflicts in relation to pursuit of other policy objectives and how were these conflicts expressed?

(3) How has full employment actually or apparently changed in the ranking of key policy goals over the period?

Data sources include public documents such as departmental reports and Reserve Bank of New Zealand (RBNZ) publications; reports of quasi-official bodies including the Monetary and Economic Council (MEC), National Development Council (NDC) and New Zealand Planning Council (NZPC), and parliamentary statements contained in New Zealand Parliamentary Debates (NZPD).

* Lecturer, Department of Economics, University of Auckland. I acknowledge the contribution of my research assistant, Pauline Nesdale, in preparing this article. Thanks to Brian Silverstone, Ken Jackson, the Editor and participants of a seminar in the Department of Economics, Auckland University for their comments. I am especially grateful to Arthur Grimes and a referee of this journal for extensive criticisms. Errors and opinions in this article are my own. 


\section{'Full employment' in the 1950 s}

The government's explicit commitment to full employment was embodied in the Employment Act 1945 which was promulgated "for the purpose of promoting and maintaining full employment". Section 5 of this act stated that the Government was to "do all things necessary" and "at all times" to achieve full employment. The Department of Labour Act 1954 reinforced this commitment. The Minister of Industries and Commerce in commenting on this legislation, argued that "[a]) II the Government set out to do as a matter of general policy, was to see first, that there was full employment" (NZPD, 304, 1954, p.1852) Emphasis added). New Zealand was also obliged to promote full employment under Articles 55 and 56 of the UN Charter. The Government did not accede to a Un Economic and Social Council request in 1950 to set a quantitative standard for national full employment. According to the RBNZ, "the New Zealand government does not expect to publicise any full employment standard over the next few years" and "the matter of determining any numerical standard has no urgency" (1954, p.11), although, in one place the RBNZ suggested "under 1 per cent of the working population" might serve as a yardstick (1955, p.87). However, officials who compiled the New Zealand Economic Survey (NZES) (1956, p.29) argued that "one percent of New Zealand's labour force would be approximately 8000 persons, but few New Zealanders would now regard the existence of that number .... as consistent with ... full employment". Prevailing social attitudes required that employment be available for all people willing and able to work. Taken literally, this total employment conception of full employment meant no unemployed persons, frictional or otherwise. The Government Statistician summarised one official line on this: "I would deplore the suggestion ...that some frictional unemployment is desirable" (Wood, 1953, p.141). In comparing policy views in Britain with other countries in the 1950 s, Hutchison noted "the almost overriding position on a scale of social preference which ... is accorded to the objectives of high, full, or even as in New Zealand total employment" (1968, p.237). He alluded to the tendency "to make a moral issue out of any unemployment and hold to a target of total employment, as in New Zealand where 0.5 percent unemployment provokes angry public protest" (p.247n.1) (Emphasis added). Full employment understood in terms of total employment acquired an atmosphere of sanctity in public documents and was rarely qualified or analysed critically (See Budget, e.g. 1954 , p.36; 1955 , p. $26 ; 1957$, p.7).

Two reports raised the level of debate surrounding unqualified acceptance of the total employment concept. A Treasury report (RBNZ,1955, p.117) argued for the avoidance of any unemployment except frictional unemployment. The RBNZ (1954, pp.31-32, 35) distinguished between a policy which achieved full employment and policy which pursued an undesirable state of "over full employment" where the number of vacancies outweighed registered unemployment. The goals of full employment and price stability were conjoined in this report; the labour force was

fully occupied .... when the people are engaged in the occupation where they are most productive. [Full employment meant that] the needs of those who are willing and able to spend can be satisfied without any usable resources being left idle ... [and when] there will be no tendency for prices to rise or fall, though individual prices may of course vary
considerably.

This more sophisticated view was not widely accepted. The term "over full employment" was used sparingly in other reports. One point is clear: no one was sure what level of vacancies represented a feasible full employment ceiling above which there was over-full employment. Government politicians, in saying the latter was "not a good thing" were equally unsure and were often severely reproved by their opponents for using the terms, (NZPD, e.g. 309, 1956, pp.1246, 1358-9).

The economic philosophy underlying economic policies in New Zealand prior to balance of payments problems in 1957-58 treated the question of full employment as a short run problem of internal demand management and not explicitly as a problem of export-led growth and international competitiveness. Going by the complaints of a minority of 
reports surveyed, the majority of policymakers neglected to appreciate in any sophisticated way, Keynesian ideas on under-employment equilibrium eleborated in terms of a "closed" economy in the context of a fairly internationally dependent economy. The minority views are contained in more guarded, analytical contributions. ${ }^{1}$ Policies for full employment were, for a large part of the decade, based on a vulgarised Keynesianism. Raising the level of employment was for a long period compatible with both more investment and consumption. It helped promote other policy objectives such as (slow) economic growth although this was hardly an immediate, top priority because of fears about insecurity and instability that "going for growth" (or development) engendered. (Parker, 1953, p.4). The price of pursuing "total employment" was lower real incomes and few reports took issue with this. It was perhaps fortuitous that price and balance of payments stability were for the most part maintained, but productivity suffered. As Franklin argued:

A low overall increase in productivity in the post-war era was the price of full employment - it would appear. Or perhaps more fairly, under the conditions imposed by the structure of the economy and the preferences of the population, full employment was attainable only through expansions of low productive jobs in both the manufacturing and tertiary sectors. The commitment to full employment meant the provision of employment for the sake of employment with only a partial concern for the sort of goods and services produced. (1978, p.123) (Emphasis added).

Productivity gains from a fully-employed labour force in the 1950 s were mostly of a oneoff variety which did not guarantee permanently higher growth rates.

Weststrate maintained for the 1950 s that "full employment seemed to exist spontaneously, there was no need to promote it" (1959, p.132). ${ }^{2}$ Apart from words of wisdom from Treasury and RBNZ, consideration of trade-offs between the full employment goal and other goals, whether achieved spontaneously or otherwise, was immensely simplified (as evidenced by conflicting policy responses and by the expressions of politicians). ${ }^{3}$ The goal of price stability played a subservient role as long as full employment was predominantly interpreted as the total employment of a homogenous labour force. When a balance of payments problem threatened pursuit of full employment in 1958, the Minister of Finance guaranteed to "ensure any reductions in living standard . . . is spread fairly throughout the community without hardship or unemployment" (Budget, 1958, p.1) (Emphasis added). Sutch (1968, pp.65-69) illustrated the priority of total employment at this time. Policy responses revealed sharp political sensitivity to any unemployment. Sutch documented with approval how the Government dealt with a "heavy economic blow" suffered from 1957-1959. Full employment as a short-term goal retained its top position on the scale of policy preference. Sutch added that an "important sustaining factor" for the ranking of full employment above growth was the "attitude of the people". Attempting to reconcile the objective of international payments stability at fixed exchange rates with total employment was a challenging assignment for policymakers. A policy of insulation helped. The hand of Micawber also assisted - export prices improved (Danks, 1960). By 1960 , in contrast to views expressed by the Minister of Finance in 1958, there was less official confidence that adverse changes in the terms of trade could be dealt with without threatening full employment. ${ }^{4}$ There was little said on how policy would be conducted in these circumstances if full employment could not be attained.

Official reports reveal that during the 1950s, total employment was aimed for. However official unemployment statistics may be adjusted for the period, it appears that full employment in the sense outlined by Beveridge was achieved in New Zealand. (See Appendix).

1 See Webb $(1953$, p.13, 15, 25-26), Treasury in RBNZ (1955, pp.121-2) and the statement of a Treasury official (Schmitt, 1953).

2 See also Ruth (1950, p.102 and 1953, pp.14-15) and Sutch cited in Parker (1953, p.8).

3 See Condliffe (1959, pp.146, 376n, 24).

4 See McLeod (1960) for a "Treasury view". 
For Beveridge, "Full employment means that unemployment is reduced to short intervals of stand by ... It means having always more vacant jobs than unemployed men" (1945, p.18). With the attainment of full employment in the 1950s, public documents gradually shifted during the early 1960s toward discussion, not merely for matters concerning economic security and stability under conditions of full employment, but of the ways and means of ensuring that these conditions obtained in a growing economy with minimal inflation. ${ }^{5}$

\section{Demise of the total employment concept in the 1960 s}

Legislation during the 1960 s drew away from reaffiring the full employment goal. The Act to establish the MEC in 1961 directed the council to "make reports ... . on ... full employment" (s. 1 a). The Reserve Bank Act 1964 did not use the term full employment. Rosenberg (1961, p.6) suggested that the International Financial Agreements Act 1961, in endorsing the IMF constitution, was a serious threat to "continuous full employment" and a vote for "employment fluctuations". There was some "useful rethinking" of economic policy associated with IMF membership (Hawke 1973, p.128). Presumably, this included a gradual change in official attitudes to, and reinterpretation of "continuous full employment" as conceived in the 1950 s.

A Labour and employment gazette editorial in 1962 announced "No change in full employment". It used the term in a Beveridge sense to describe current labour market conditions. Unemployment increased markedly during 1962 but the Department was sure that full employment had been preserved. There was less suggestion that full employment had connotations of continuous total employment. Some Labour politicians tried to defend the total employment view in the early 1960s but this was rebuffed by Government members as over-full employment. (NZPD, 326, pp.363, 370, 385; Budget 1961 passim and $1962, p .7)$. The Government was still determined to make "full employment the number one requirement in the management of the economy" and its monetary policy reinforced this commitment. (NZPD, 330, p.603; Hawke 1973, p.162). A view which was previously held by a minority and which was first fully elaborated by the RBNZ in 1954 , was now more prevalent. It was restated in the RBNZ Bulletin (May 1961, p.60):

to many people full employment means full employment no matter what and in its elevation to the basically sound idea of full employment New Zealand has very inadequately achieved some other objectives, e.g. price stability (Emphasis added).

Employment conditions summarised for the period 1960-61 in the Appendix show a Beveridge state of full employment, but the Deputy Governor of the RBNZ was sure that these conditions were indicative of over-full employment which "bears as much resemblance to true full employment as high blood pressure does to normal blood pressure" (p.61). This viewpoint implied that some unemployment was not only inevitable but desirable in the interests of greater price stability. In contrast, the Report of the Department of Industries and Commerce $(1962$, p.5) judged that "labour . . . should be fully employed at all times". With this vague notion the Report recommended import controls if full employment conflicted with the balance of payments constraint. ${ }^{6}$ On the other hand, the MEC (1963, No. 4, p.22) developed a rival view that full employment could best be promoted by diverting more labour toward export industries. Complaints by the MEC (1966, No. 10, p.174) about the "ill-defined" status of economic policy goals which pervaded official reports in the 1960s, were substantially justified. In the 1950 s the Government did not state full employment in numerical terms; now the MEC was saying that an operational target was "a necessary prerequisite to a consistent set of economic policies open to public criticism and judgement". Well before the balance of payments problem in

5 This was the main theme in the Budget 1963 to 1965.

6 See also Sutch (1962, pp.8-9 and 25-27). 
1967, the MEC attitude was that "undue weight" on the full employment objective "has meant that we have failed to secure stable prices or balance of payments equilibrium and our rate of economic growth has suffered". Further, "continued import substitution" was regarded as an "undesirable effect" of pursuing full employment. This MEC report opened a tacit challenge to a view, so common throughout the 1950 s and early 1960s, "that policy alternatives in New Zealand no longer include unemployment as a solution to the balance of payments". (Department of Industries and Commerce 1962, p.5). Whereas previously the full employment goal was defined as a stable, secure state which had been attained or it was hoped to attain in the short-term come what may, it was, by 1966 , becoming a matter of direction in which it was hoped to move given alterations in the economic structure. It was now more officially respectable to express dissatisfaction with any kind of employment which assisted in the maintenance of a state of zero unemployment.

Most reports leading up to the balance of payments crisis in 1967 described economic circumstances without recognising the need for more explicit value judgements about policy priorities. Events, however, began to conspire against, and eventually overtook these habits of thought. (See Zanetti 1967). The RBNZ maintained that "measures for securing necessary adaptation in New Zealand's balance of payments ... must receive highest priority" and "inevitable ... unemployment" (RBNZ 1968, October, p.168, 218) was the result. These reports refrained from saying whether the extent of subsequent unemployment meant a sacrifice of full employment. The Minister of Finance indicated a revision in ranking of the full employment goal in his 1967 Budget (pp.7-8) which for the first time in the history of the Budget during the 1960s contained a section devoted to "employment". It discussed government special works and job creation. The Department of Labour (Annual Report 1968, p.5) responded by extending its manpower planning and employment services. The creation of unemployment was taken for granted. The Minister of Finance was concerned only that "persons who become unemployed do not remain so for any long period of time". In this view, it was satisfactory to have an active pool of labour which could be trained and retrained in response to changing labour market conditions. This was regarded as an electorally "vulnerable" policy stance (Muldoon 1974, p.111). It was also incompatible with both short-term full employment considerations and the public's "paranoiac attitude towards unemployment" at the time (Muldoon 1977, p.60). Official documents still viewed policy as consistent with full employment on a longer time horizon.

By the 1968 Budget the revision of goal rankings became clear: "first priority had to be given to the overriding need to regain equilibrium in New Zealand's balance of payments" (p.3). The Budget did not mention alternative policy instruments, especially import controls which may have put full employment within short-term grasp. Solutions advocated in theory by Keynesians did not apply to New Zealand where, ceteris paribus, the tendency to import, as full employment was approached, exceeded export earning ability. Full employment was sacrificed deliberately though not explicitly. The possibility of forfeiting full employment during 1968 was admitted and camouflaged in a new vocabulary. Key words were economic "flexibility" and "efficiency". (NZES, 1967, p.12, and Budget, 1968 , p.3). The MEC was more direct in stating goal conflicts; in its view the era of full employment had temporarily and inevitably come to an end (1968, No. 14, p.11), and "unemployment is one of the results of internal restraints needed to cure ... the balance of payments problem" (1968, No. 15, p.10) (Emphasis added). On the other hand, the Department of Labour without mentioning the full employment goal which it had been given the responsibility to protect in its governing legislation, obliquely justified the rise in unemployment by repeating an official statement that "pressure on available resources were becoming a little too intense" (Labour and employment gazette, 1967, November, p.8).

It was not spelt out by Government in the late 1960 s exactly which groups or industries in New Zealand were likely to lose by the new policy stance which conceived of full employment as a longer term aggregative policy goal. There were still vestiges of the more 
short-run continuous "total employment" view in some quarters. One merit of this view was that it highlighted the differential social impact of the new concept of full employment. For example, W.B. Sutch, in commenting on the way the Government dealt with the "heavy economic blow" in 1967, said that the

\begin{abstract}
main contributions New Zealand has made to justify its existence were its practice of economic quality and its real achievement with full employment. Now these were to go ... [;] the aim was to ... produce a situation where unemployment was a normal part of social and economic life (1968, pp.187-8).
\end{abstract}

The Government persisted with an aggregative definition of full employment which glossed over issues of equality. Losses from increasing unemployment were weighed against gains on the balance of payments. To argue no further than this was to take the distribution of increased unemployment as unproblematic. No considerations of the equity effects of policies adopted during 1967-69 are evident in public documents. Officials dealing directly with the unemployed through the Department of Labour (see Annual report, 1969, pp. 4 and 10) concentrated on devising practical solutions rather than on issues surrounding the choice of macroeconomic policies which had created what, in its view was some "prolonged and chronic insecurity of employment".

Clashes of economic goals with the full employment goal were immediately and practically involved in responses to the balance of payments crisis in the late 1960s. In moving away from reaffirming both the full employment concept and employment record of the 1950 s and early 1960s, the Government did not convincingly express policy trade-offs connected with full employment in a way that justified the inevitability of actual policy
responses.

\title{
"Full employment" : from the NDC to NZPC
}

One outcome of the plenary session of the NDC was a re-evaluation of economic policy objectives including full employment. According to the Manufacturing Committee full employment had the potential to trade-off with growth so "one of the most important modifications [to a growth policy] must be the accepted social objective of full employment of human resources" (1969, pp.5-6). Economic growth was no mere appendage to full employment policy as in the 1950s. Roles were now reversed. The Committee set 3 grand objectives : (1) rapid economic growth; (2) earnings or economising on foreign exchange with emphasis on exports and (3) "consistency [of (1) and (2)] with the social objective of full employment". NDC discussion was not based on a clear weighting of the different economic policy objectives nor a lucid formulation of the meaning of full employment. (See Young, 1972). While many national and sectoral targets were set by the NDC no target was set for "full employment" or for a minimum standard of unemployment. (See Low, 1970). The Task Force $(1976$, p.22) was moved to conclude that the NDC "had tended to evade rather than face up to the fundamental issues of determining priorities". To be fair, the NDC Labour Committee took steps to point out that a policy mix aimed at full employment need not guarantee every worker continuous employment since "the economy demands ... occupational, industrial and geographic movement of labour". Such a guarantee could now threaten long-term full employment prospects. Further, the Committee did "not advocate a return to the economic position prior to 1967 when inflation trends in the economy were prevalent" (p.18). Underlying this view was a judgement about the ranking of objectives. Economic conditions prior to 1967, while approximating full employment (Beveridge-type), were inimical to what was then conceived as price stability.

The MEC (1970, No. 20, p.26) began a new decade by recommending changes in economic policy on the grounds that "the present position of $2 \frac{1}{2}$ notified vacancies ... for every person registered as unemployed must be corrected". This report held a clear implication that more unemployment was in store if its various recommendations were accepted. The Government was already adopting policies during 1970 to alter labour 
supply and to "ensure that labour is not retained in a sector where it could be better employed elsewhere" (Budget, 1970, p.11). It was being advised by the MEC to reduce the demand for labour and it was not anxious to reduce unemployment below the level recorded for 1969. The record shows that for 1971, the full employment target (Beveridge-type) was attained (See Appendix). The ad hoc collection of deflationary policies directed at price stability in 1970 were being hastily revised by mid-1972 to counter what was now a reverse situation to that identified by the MEC in 1970. Figures in the Appendix show a December year average of over 2 registered unemployed per vacancy in 1972. Full employment had been forfeited. Policy choices in the 1972 Budget were essentially expansionary and shortterm. Notably, the MEC did not recommend drastic policy changes to counter this reversal in employment conditions - it evidently valued price stability more highly. Although, it did not accept a simple Phillips curve relation: "the deliberate creation of unemployment might not help to reduce inflation" (1971, No. 22, p.37). The MEC (1972, No. 23, p.51) observation that many of the unemployed were "having considerable difficulty finding work" was not compatible with full employment conditions (Beveridge-type). ? The MEC as with the RBNZ (September 1972, pp.538-41) recommended job creation schemes. It was not obvious that these schemes would not have the inflationary side effects which it was feared, in these reports, would ensue from traditional expansionary monetary and fiscal policies. Such schemes were viewed as temporary instruments for relieving hardship rather than as means of achieving a stable long-run level of full employment. The Royal Commission of Inquiry on Social Security (1971, p.291), held to a continuous, total employment view at this time. Per contra, the MEC and RBNZ were insisting that the government could no longer satisfactorily manage the economy in this spirit.

Circumstances in 1973 allowed full employment to return to the foreground of economic policy. It re-appeared in the new Government's 1973 Budget (p.13). Full employment was established as top priority. The goal was specified in three dimensions: (1) universality - jobs for all who desired work; (2) employment continuity and security and (3) an unprecedented concern for the qualitative aspects of employment (Budget, p.42 and 1975, p.21). The Department of Labour chimed in; full employment had "social aspects". The "concept of full employment" so the Department argued, had "undergone changes. From a concern ... that all breadwinners be employed, people have come to expect more from work" (Labour and employment gazette 1974, August, p.7). All this sounded like luxurious speculation by the end of 1975 when full employment (Beveridge-type) was far from realised (See Appendix). Another balance of payments crisis was at hand. The MEC (1975, No. 28, p.36) was of the opinion that "there appears to be no necessity for substantial unemployment to occur". And the RBNZ Annual report spoke of a "small amount of unemployment" which was "manageable" (1975, p.8). Neither report made reference to a full employment goal or warned that such a goal may be threatened. The Government's "determination to attain and sustain full employment" oft repeated in the NZPD during 1974 (e.g. 394, pp.4425, 5231), was now less convincing. During 1975, the Government justified historically high overseas borrowing to "prevent tens of thousands of New Zealanders from being thrown out of work" (Budget, 1975, p.2). Despite these sentiments, reference to full employment was absent from this Budget. There was stress on the importance of maintaining high levels of employment (p.34) but not full employment.

Full employment was interpreted in a new light during 1976. Conflicts of objectives were more sharply delineated, no more so than in RBNZ publications and the Budget, culminating in a detailed account of conflicts in the Task Force Report (1976). Whereas in 1975 the Department of Trade and Industry conceded that an economic policy of "restrictive demand would have ... rendered unattainable the policies of full employment" (Annual report, p.7), in 1976 it levelled a veiled criticism at the previous Government by arguing that "there was the tendency [in 1975] to mortgage tomorrow's expansion ... to maintain employment" (p.5). The balance of payments had priority from 1976 and there was no questioning the view that export-led growth was the way out. The RBNZ (1976,

7 See also Department of Labour Annual report (1972,p.8) 
April, p.79) in accepting this view noted in a tone of desperation: "we don't have a great deal of choice". The Industries Development Commission (IDC) report (n.d. pp.49, 76) on the textile industry supported export-led growth and mentioned full employment in the sense of a long-term goal. The IDC plan, so the argument proceeded, should not be distorted by "short-term exigencies of the employment problem". In support of export-led growth the Task Force (1976, p.xi) concluded that most New Zealanders regarded "a reasonable rate of economic growth" as an important policy goal, provided that the costs involved in its pursuit were "minimal" (1976, p.xi). It did not see a conflict in context and especially over the long term, between export-led growth and full employment. With growth it is easier "to make changes in the structure of the economy" although - and this is where the full employment goal could be compromised - growth "does not operate equally in favour of all groups and thus it can lead to tensions, and social inequities" (pp.33-35). One cost of growth and especially of restructuring via what was championed a "more market" policy during the late 1970s (e.g. NZPC No. 11, 1979), is the tendency for job losses and unemployment duration to be uneven in their impact upon labour markets disaggregated by race, sex, age, region and occupational group. All too often these impacts on "full employment" considered at the micro-level were passed over or received only fleeting mention in public documents. For example, RBNZ reports considered full employment exclusively from a macro-standpoint. The Bank advised that it would be "unwise" to deal with "necessary adjustment" by further overseas borrowing (Annual report, 1977, p.8). Later, "the unavoidable costs of this adjustment process" were recorded in a "massive increase in unemployment" (Annual report, 1978, p.8) which by the 1979 report was being described as "large scale" and "a major problem to grapple with" (p.8). The RBNZ finally conceded in its report to March 1978 (following a year to December 1977 which showed nearly 5 registered unemployed per vacancy) that "after many years of being able to maintain full employment", New Zealand had now begun to falter (p.7). From 1975-79 the RBNZ did not identify where job losses were to take place to serve "necessary" and unavoidable adjustment or who was to be affected. It is only after unemployment appeared in a "massive" form that the RBNZ Bulletin (1980, November, p.447) began to point out that the problem of displaced workers "cannot be ignored" even though it was continuing to recommend further " $[\mathrm{r}]$ ationalisation of domestic industry" which may "cost some jobs". The questions of how many jobs, the duration of resulting unemployment and the
regions or groups affected were not elaborated upon.

The Economic Monitoring Group (1978, No. 1, p.11) observed, during a period of historically high increases in unemployment, that policies should be oriented toward "selective stimulation". It recommended more interventionist job creation policies. Special works were now an avenue for regaining full employment - at least those engaged on such works should not be associated with the unemployed (p.23). The relative insecurity of special work and subsidised jobs did not seem to matter. This view is also common in Department of Labour reports (1978, pp.9-10 and 1979, p.18) despite the fact that some schemes were providing temporary, demeaning employment. Repeating an approach of the late 1960s, the Department of Labour concentrated on practical solutions to unemployment. The micro-level impact of macroeconomic policies on employment is well sketched in its reports but there is no discussion of the full employment goal relative to other key economic objectives. In comparison with the RBNZ, the Department was also concerned about the duration of unemployment. A Department of Labour document showed that for the period March 1976 - March 1980, long term unemployment (registered more than 8 weeks) increased from 26 percent to 32.7 percent (1980, Table 7). In sharp contrast, the RBNZ was claiming without justification that the rationalisation of industry "may lead to some short-term loss of jobs" (Annual report, 1980. p.7) (Emphasis added). The grounds for thinking that departure from any semblance of full employment through restructuring was of a short-term nature were rather shaky in the light of duration indices available at the time. The 1978 Budget (pp.6, 11, 43) was clear in its statement of priorities - the "dangerous level" of inflation and the overseas deficit meant that a retreat from full employment was "inevitable". Job creation schemes were detailed. The 1979 Budget 
(p.29) endorsed a greater variety of job creation schemes. There was a strong suggestion that these schemes were policies for full employment. The discussion of these schemes ended with the statement: "[ $\mathrm{t}]$ he Government remains committed to the objective of full employment". Job creation according to the Minister of Labour was a way of providing employment until economic growth was forthcoming (NZPD, 434, 1980, p.4387). Concern for the job continuity and quality aspects of employment, noticeable in a definition of full employment advanced by the Government in 1973, had all but disappeared.

Full employment was left undefined in NZPC No. 4 (1978, pp.89-90). A section heading read "Full employment with less inflation". The NZPC used full employment as no more than a byword. Numerical data was not used to serve the purpose of showing precisely what the term meant in practice. The NZPC was of the view that, "in a world subject to rapid and unpredictable change, it is inappropriate to lay down a rigid blue-print or set of numerical targets" (p.3). The last NZPC report over the period under review set a new definition of full employment. The "traditional full employment goal" was considered to mean "low numbers of registered unemployed" (1980, No. 17, p.18). On the other hand, the NZPC defined full employment as "a situation where there is an approximate balance between those who want paid employment and the jobs available, such that those who want paid employment can obtain it, or training leading to it, within a reasonable period after commencing a job search" (p.17). This definition, described as "an appropriate goal for the future" (p.18), has a striking resemblance to Beveridge's definition quoted earlier. Beveridge had discussed his definition in connection with vacancy data. The NZPC did not analyse unemployment - vacancy ratios despite the fact that the definition advanced spoke of a balance between those wanting work and "jobs available". Otherwise, the NZPC Beveridge-type treatment of full employment was developed in the context of nearly 6 years' failure to achieve full employment in the sense defined.

\section{Conclusions}

Full employment conceived as total employment was for the most part a sacred cow during the 1950s. It was worshipped with much less fervour in the 1960s. The order of full employment in the ranking of key policy goals was sometimes adjusted with the experience of balance of payments crises. Opinions differed over how to reduce unemployment in the short-term as opposed long-term, and over what amount of unemployment represented the achievement of full employment. These opinions were influenced by levels of unemployment experienced in the past. At the end of the period under review, policymakers appeared to tolerate a higher level of "short-term" unemployment, as a condition for attaining full employment at a future date, than they would have at the beginning. Perceived opportunity costs - in terms of foregoing policy objectives such as higher real incomes - of pursuing full employment more immediately, increased over the 30 -year period. A new view was emerging in the late 1970s: the state of full employment in a more flexible, outward-looking economy potentially within New Zealanders' grasp in the 1980s was to carry less of a prolonged job security connotation than earlier.

Policymakers urged the compatibility (or otherwise) of full employment with other policy goals in a form too vague to be validated at the time or even with the benefit of hindsight. Full employment was too often viewed in aggregative rather than structural terms. Single rates or measures of unemployment for the labour force as a whole hid differential hardship which resulted from demoting the full employment goal. By the early 1970 s, in contrast to earlier decades, most policymakers did not share the concern of Sutch (and Rosenberg) to maintain the employment record of the 1950s. It was precisely that which Sutch and Rosenberg feared - namely New Zealand's excessive reliance on an unstable world economy to generate higher real incomes - which had a significant impact on attitudes to full employment in the late 1970s. 


\section{Tony Endres}

\section{Appendix}

Registered unemployed and vacancies 1950-1980(a)

\begin{tabular}{|c|c|c|c|}
\hline Year & $\begin{array}{l}\text { (1) } \\
\text { Registered } \\
\text { unemployed }\end{array}$ & $\begin{array}{c}(2) \\
\text { Notified } \\
\text { vacancies }\end{array}$ & $\begin{array}{c}(3) \\
\text { Vacancies to } \\
\text { registered unemployed } \\
(2) \div(1)\end{array}$ \\
\hline 1950 & 38 & 22445 & 590.6 \\
\hline 1951 & 38 & 21968 & 578.1 \\
\hline 1952 & 47 & 17647 & 375.4 \\
\hline 1953 & 85 & 11399 & 134.1 \\
\hline 1954 & 58 & 12532 & 216.1 \\
\hline 1955 & 56 & 14854 & 265.2 \\
\hline 1956 & 259 & 12986 & 50.1 \\
\hline 1957 & 394 & 8926 & 22.6 \\
\hline 1958 & 785 & 7135 & 9.1 \\
\hline 1959 & 1188 & 5300 & 4.5 \\
\hline 1960 & 633 & 6764 & 10.7 \\
\hline 1961 & 376 & 9196 & 24.5 \\
\hline 1962 & 1040 & 6843 & 6.6 \\
\hline 1963 & 849 & 5731 & 6.8 \\
\hline 1964 & 650 & 6613 & 10.2 \\
\hline 1965 & 513 & 7936 & 15.5 \\
\hline 1966 & 463 & 7753 & 16.7 \\
\hline 1967 & 3852 & 4127 & 1.07 \\
\hline 1968 & 6881 & 2680 & 0.39 \\
\hline 1969 & 2926 & 4167 & 1.4 \\
\hline 1970 & 1600 & 5245 & 3.3 \\
\hline 1971 & 3115 & 3158 & 1.01 \\
\hline 1972 & 5684 & 2647 & 0.47 \\
\hline 1973 & 2321 & 3538 & 1.5 \\
\hline 1974 & 955 & 4556 & 4.8 \\
\hline 1975 & 4166 & 2051 & 0.49 \\
\hline 1976 & 5356 & 1666 & 0.31 \\
\hline 1977 & 7385 & 1523 & 0.21 \\
\hline 1978 & 22330 & 1751 & 0.08 \\
\hline 1979 & 25239 & 1687 & 0.07 \\
\hline 1980 & 36499 & 1476 & 0.04 \\
\hline
\end{tabular}

Source: Monthly abstract of statistics various issues.

Notes: (a) December year monthly averages.

(b) Includes only vacancies notified to District Offices of Department of Labour in its capacity
as placement service. 


\section{References}

Beveridge, W (1945) Full employment in a free society London, Unwin.

Condliffe, J B (1959) The welfare state in New Zealand London, Unwin.

Danks, A (1960) The New Zealand Economy Economic record 36(76): 465-478.

Economic Monitoring Group, (various issues) Reports Wellington.

Franklin, H (1978) Trade, growth and anxiety: New Zealand beyond the welfare state Wellington, Methuen.

Hawke, G R (1973) Between governments and banks Wellington, Government Printer.

Hawke, G R (1983) Unemployment in New Zealand. In Harbridge R,(Ed) Industrial relations : insights and directions Wellington, Industrial Relations Centre, Victoria University of Wellington.

Hutchison, T W (1968) Economics and economic policy in Great Britain 1946-1966 London, Unwin.

Industries Development Commission (various issues) Reports.

Low, A (1970) Indicative planning - the New Zealand experience Australian economic review 3rd Quarter: 20-24.

McLeod, S (1960) New Zealand's living standards and full employment Proceedings of the industrial development conference Treasury background paper, June.

Monetary and Economic Council (various issues) Reports Wellington.

Muldoon, R D (1974) Rise and fall of a young turk Wellington, Reed.

Muldoon, R D (1979) Muldoon Wellington, Reed.

National Development Council (various issues) Reports, Wellington.

New Zealand Department of Industries and Commerce (various issues) Annual reports Wellington.

New Zealand Department of Labour (various issues) Annual reports Wellington.

New Zealand Department of Labour (1980) An overview of the employment situation and major trends in research on unemployment, Proceedings of the New Zealand demographic society conference Wellington, June.

New Zealand Department of Trade and Industry (various issues) Annual reports Wellington

New Zealand Government (various issues) Budget Wellington.

New Zealand Government (various issues) New Zealand economic survey Wellington.

New Zealand House of Representatives (various issues) Parliamentary debates (Hansard) Wellington.

New Zealand Planning Council (various issues) Reports Wellington.

Parker, R S (Ed) (1953) Economic stability in New Zealand Wellington, New Zealand Institute of Public Administration.

Reserve Bank of New Zealand (various issues) Annual reports Wellington.

Reserve Bank of New Zealand (various issues) Bulletin Wellington.

Reserve Bank of New Zealand (1954) Employment of economic resources Wellington.

Reserve Bank of New Zealand (1955) Monetary and fiscal policy in New Zealand Wellington.

Rosenberg, W (1960) Full employment: can the New Zealand miracle last? Wellington, Reed. 


\section{Tony Endres}

Rosenberg, W (1961) What every New Zealander should know about the IMF; why New Zealand should not join Christchurch, Monthly Review.

Ruth, N (1950) Full employment in New Zealand Economic Record 26(50): 98-103.

Ruth, N (1953) National insurance and the doctrine of full employment Australian quarterly September: 10-20.

Rowe, J W (1972) New Zealand. In Perkins J O (Ed) Macroeconomic policy: a comparative study London, Unwin.

Royal Commission on Money, Credit and Banking Systems (1955) Proceedings Wellington. Royal Commission on Social Security (1972) Report Wellington.

Schmitt, G (1953) Economic stability and the balance of payments. In Parker R S (Ed) (1953).

Sutch, W B (1962) Problems of prosperity Wellington, Price Milburn.

Sutch, W B (1968) Colony or nation? Sydney, Sydney University Press.

Task Force on Economic and Social Planning (1976) New Zealand at the turning point Wellington.

Treasury, (1955) Second supplementary statement to the Royal Commission on Money.

Webb, L C (1953) The making of economic policy. In Parker R S (Ed) (1953).

Weststrate, C (1959) Portrait of a modern mixed economy Wellington, New Zealand University Press.

Wood, G E (1953) Social accounting and economic policy. In R.S. Parker (Ed) (1953).

Young, F J (1972) Refashioning the full employment objective Proceedings of the NDC conference, May.

Zanetti, G C (1967) The New Zealand economy 1966: the failure of policy New Zealand economic papers 2: 5-15. 